\title{
Application of a non-destructive method to determine biomass in Pontederiaceae
}

\author{
Aplicação de método não destrutivo para determinação de biomassa de Pontederiaceae
}

Cátia Viviane Gonçalves ${ }^{1,3}$, Albano Schwarzbold ${ }^{1}$, André Jasper ${ }^{2,3,4}$ and Marlon Castro Vasconcelos ${ }^{1}$

${ }^{1}$ Programa de Pós-graduação em Ecologia, Universidade Federal do Rio Grande do Sul - UFRGS, Av. Paulo Gama, 110, CEP 90040-060, Porto Alegre, RS, Brazil e-mail: biologacatia@univates.br; albano.schwarzbold@ufrgs.br; castro_bio@yahoo.com.br

${ }^{2}$ Programa de Pós-Graduação em Ambiente e Desenvolvimento - PPGAD,

Centro de Ciências Biológicas e da Saúde, Centro Universitário UNIVATES, Rua Avelino Tallini, 171, CEP 95900-000, Lajeado, RS, Brazil e-mail: ajasper@univates.br

${ }^{3}$ Setor de Botânica e Paleobotânica - SBP, Museu de Ciências Naturais - MCN, Centro Universitário UNIVATES, Rua Avelino Tallini, 171, CEP 95900-000, Lajeado, RS, Brazil

${ }^{4}$ Conselho Nacional de Desenvolvimento Científico e Tecnológico (CNPq), Brazil

\begin{abstract}
Aim: The aim of the present study was to estimate Eichhornia crassipes biomass by a non-destructive method that uses allometric measurements of foliar structures; Methods: Aquatic macrophytes collected at different growth in a wetland were allometrically measured as (a) limbo length and width (b) petiole width and diameter. The same leaves were used to determine biomass, expressed in dry weight, after drying in an oven at $70{ }^{\circ} \mathrm{C}$ until constant weight; Results: The correlation between petiole length/ diameter with foliar biomass was $r^{2}=0.7705 ; p<0.001$, and between limbo width/length and foliar biomass was $r^{2}=0,8838 ; p<0,001$. It was shown that limbo width/length and petiole length/diameter are related to biomass. Two estimation models were built to estimate aerial biomass based on allometric and biomass data; Conclusion: Biomass values obtained with the model proposed in this study are similar to those obtained when the material was dried in the oven, as determined by the $t$ test. The biomass determination model proposed in the present study was shown to be efficient, and allows the follow-up of plant growth in time.
\end{abstract}

Keywords: wetland, water hyacinth, modeling, allometry.

Resumo: Objetivo: O objetivo deste estudo é a estimativa de biomassa de Eichhornia crassipes por método não destrutivo, em ambiente natural, através de medidas alométricas de estruturas foliares da planta; Métodos: Foram feitas medidas alométricas do (a) comprimento e largura do limbo e (b) diâmetro do pecíolo de folhas de aguapé, em diferentes estádios de crescimento, coletadas de um banhado colonizado por macrófitas aquáticas. Das mesmas folhas medidas foi feita a determinação da biomassa, expressa em Peso Seco, após secagem em estufa a $70{ }^{\circ} \mathrm{C}$ até peso constante. Após, foi estabelecida a correlação entre os valores das medidas alométricas e o peso seco, com aplicação do Teste t; Resultados: A relação entre comprimento/diâmetro do pecíolo e a biomassa foliar foi de $r^{2}=0,7705 ; p<0,001$. A relação entre largura/comprimento do limbo e a biomassa foliar foi de $r^{2}=0,8838 ; p<0,001$. Demonstrou-se que existe relação entre medidas de comprimento/largura do limbo e comprimento/diâmetro do pecíolo e sua biomassa. A partir dos dados alométricos e dos de biomassa, pôde se determinar dois modelos de estimativa de biomassa para a parte aérea; Conclusáo: Os valores de biomassa obtidos a partir do modelo aqui proposto quando comparados com os valores obtidos com secagem do material em estufa, mostraram-se similares pelo Teste $t$. O modelo de determinaçáo de biomassa utilizado neste estudo se mostrou bastante eficiente e vantajoso, podendo propiciar o acompanhamento do crescimento vegetal ao longo do tempo.

Palavras-chaves: banhado, aguapé, modelagem, alometria. 


\section{Introduction}

Wetlands cover large extensions in the tropics, especially in Brazil. These areas have important functions in the landscape: they store water, balance local climate, integrate the cycle of biogeochemical elements, and house highly-adapted plants and animals (Jepsen and Winemiller, 2002).

Aquatic macrophytes are the organisms that best characterize the wetlands, considering that they are well adapted to waterlogged areas. In addition, aquatic macrophytes usually have wider geographical distribution than most terrestrial plants, due to the higher homogenization of the environmental conditions of the wetlands, allowing cosmopolitan species (Irgang and Gastal Jr., 1996).

Aquatic macrophyte evaluations require a preliminary analysis to verify and quantify the variables to be studied, such as organic matter, dissolved oxygen, temperature, and biomass (Thomaz et al., 2004; Demars and Edwards, 2009).

Macrophyte biomass balance in aquatic environments can be determined by destructive (Downing and Anderson, 1985; Piedade et al., 1991; Costa, 2005; Engle et al., 2008; Silva et al., 2010; Soti and Volin, 2010) or non-destructive methods, which are also known as indirect phenometric, morphometric or allometric estimation (Hopkinson et al., 1980; Morris and Haskin, 1990; Daoust and Childers, 1998; Thursby et al., 2002; Gouraud et al., 2008; Miao et al., 2008).

According Thomaz et al. (2004), the destructive method is more accurate and efficient; however, it destroys the samples. In order to circumvent this problem, destructive methods in small plots are used and the obtained data are then extrapolated to produce a general view of the assemblage. On the other hand, the non-destructive method does not require destruction of the samples, allowing more comprehensive sampling and the use of modelling to establish relations between the measured variables to generate predictions on the proposed objectives (Higuchi et al., 1998; Hairiah et al., 2001; Gouraud et al., 2008; Miao et al., 2008; Silva et al. 2010).

Although modelling is a simplification of the "real world" as concepts or mathematical equations (Dyn, 2004), several studies and authors use mathematical models to explain their theories, as in the case of island biogeography (MacArthur and Wilson, 1963; Watterson, 1974; Caswell, 1976; Hubbell, 1997; Chave, 2004; Chave et al. 2006;
Beeravolu et al., 2009) and in the predator-prey dynamics of Lotka-Volterra (Ricklefs, 2003).

Considering that in some cases the evaluation of aquatic environments could be very laborious due to their characteristics (very large, difficult to access, extreme conditions), it is important to develop alternative methods to perform this kind of study. Therefore, modelling associated with non-destructive methods of biomass evaluation of aquatic macrophytes will greatly help research on this field.

This study focuses on the aquatic macrophyte Eichhornia crassipes (Mart.) Solms, characterized by free floating biological form, fibrous roots, dark green leaves (sensu Simpson and Sanderson, 2002). According these authors, its leaves have an inflated petiole that enables it to float.

E. crassipes, according Gopal (1987), have vegetative and sexual reproduction; the first occurs quickly, promoting the predominance of this species in environments where it was introduced or where environmental conditions favor its growth. Vegetative reproduction consists in the formation of a stolon at the petiole base, where a new plant arises and is later released from the mother-plant. According to Soti and Voli (2010), E. crassipes biomass may double in two weeks and, in a study carried out in the Brazilian wetlands (Pantanal) by Pott and Pott (2000), it completely covered the water surface at that time, with 50 t.ha $^{-1}$ of green mass, in which, in some cases, may achieve 2000 t.ha ${ }^{-1} \cdot$ year $^{-1}$.

Considering the ecological characteristics mentioned above, and the fact that E. crassipes is a species widely distributed in South America and is considered one of most noteworthy invasive plants in another parts of the world (Lu et al., 2007; 2010; Gao and Li, 2004), the choice for this study may be considered almost "natural".

Therefore, the objectives of the present study were: 1) to develop a mathematical equation to define biomass using a non-destructive method; 2) to compare E. crassipes biomass results obtained by destructive methods with those obtained by a non-destructive method; and 3) to contribute for non-destructive species-monitoring studies.

\section{Material and Methods}

\subsection{Study area}

The plant samples were collected on a wetland area of 2.2 ha by Taquari river, Lajeado, Rio Grande do Sul, Brazil (UTM Coordinates - 22J 409137W 
$6743126 \mathrm{~N})$. The lentic system presented an overflowing free-floating aquatic macrophyte cover, in which E. crassipes was the predominant species, followed by Salvinia biloba Raddi.

Based on Köppen's climatic system, the climate in the region is subtropical humid (Moreno, 1961), with a dry season from November to March (average rainfall $90 \mathrm{~mm}$.month $\mathrm{m}^{-1}$ ) and a wet season from April to October (average rainfall $130 \mathrm{~mm}$. month ${ }^{-1}$ ). The average temperature varies between 18 and $20^{\circ} \mathrm{C}$ in the dry season, and between 12 and $15^{\circ} \mathrm{C}$ in the wet season (UNIVATES 2005).

\subsection{Biomass balance}

In total, 106 leaves of E. crassipes were collected at the study area. Two methods were used to estimate $E$. crassipes biomass: 1) a destructive method, using drying in an oven; and 2) a nondestructive method, measuring limbo width and length and petiole diameter and length (used to develop the mathematical model).

Data were collected from only one leaf of different ages was chosen at random per specimen. Leaves were numerically identified and measured on site in order to prevent turgidity losses from affecting the results.

Sampling was performed in June 2005 following the steps: I) collection of exposed leaves on the water surface; II) separation of the limbo and petiole fractions; III) measurements of the length along the central vein and maximal width across the central vein of the limbo, maximal length and transversal diameter of the petiole; and IV) drying to constant weight of the measured samples in an oven at $70^{\circ} \mathrm{C}$. Measurements were made using a digital caliper rule, model Mutitutoyo, and the drying oven was Bipolar model S330SD.

Multiple regressions were used to estimate the equation that best fitted the biomass measured variables from $E$. crassipes. This analysis allowed building a simplified mathematical model to define the biomass of that species. In September 2005, 20 leaves were collected in another sector of the studied wetland and their biomass were determined by destructive method and compared to the data obtained by the non-destructive method presented here, to check the obtained equations. Both data sets were compared by the $t$ Test. Statistical analyses were performed using Statistics Package R - 2.11.1 version (R-Project).

\section{Results}

The results of the study demonstrated that there is a relation between biomass and limbo length/width and petiole length/diameter. Petiole length/diameter $\left(\mathrm{r}^{2}=0.9 ; \mathrm{p}<0.001\right)$ is less related to biomass than limbo length/width $\left(r^{2}=0.8\right.$; $\mathrm{p}<0.001)$.

Evaluating allometric data and correlating it with the biomass allowed building the following predictive equations of biomass balance, where $\mathrm{W}$ = width, $\mathrm{L}_{1}=$ Limbo length, $\mathrm{L}_{2}=$ Petiole length and $\mathrm{D}=$ diameter (all in centimeters).

Limbo Biomass Equation 1 (in g)

$\mathrm{LB}=-0.005368-(0.004996 * \mathrm{~W})+$

$\left(0.010241 * \mathrm{~L}_{1}\right)+\left(0.07690 * \mathrm{~W}^{*} \mathrm{~L}_{1}\right)$

Petiole Biomass Equation 2 (in g)

$\mathrm{PB}=-0.011972-(0.019692 * \mathrm{D})+$

$\left(0.020722 * \mathrm{~L}_{2}\right)+\left(0.008391 * \mathrm{D} * \mathrm{~L}_{2}\right)$

A complete model was generated using the allometric data (Figures 1 and 2). However, allometric data as a set presented lower correlation with biomass as compared to the limbo and petiole models individually. Therefore, the estimation of $E$. crassipes requires adding the values obtained in both equations, resulting in the model $\mathrm{FB}=\mathrm{LB}$ $+\mathrm{PB}$ (where FB corresponds to foliar biomass). The biomass values obtained using this equation are similar to those obtained using the drying method (Figure 3). When values obtained with the destructive and non-destructive methods were compared, the test showed that the values are similar $(t$ Test $=-0.88 ; \mathrm{p}=0.38)$.

\section{Discussion}

Destructive methods (dry mass) were used by authors, such as Mahujchariyawong and Ikeda (2001), Greco and Freitas (2002), Henry-Silva and Camargo (2003), Santos et al. (2006), Silva et al. (2010), and Soti and Volin (2010) to evaluate the vegetable biomass of aquatic macrophytes. However, when determining biomass, those authors did not focus on the plants themselves, but square samplings to determine biomass. On the other hand, nondestructive methods are not frequently used, and generally are applied to establish morphological relationships (e.g. foliar surface) and not to obtain biomass balances (Hopkinson et al., 1980; Morris and Haskin, 1990; Daoust and Childers, 1998; Thursby et al., 2002; Marchi and Pitelli, 2003; Alves et al., 2004; Gouraud et al., 2008; Miao et al., 2008).

The non-destructive method applied in the present study assumes that allometric data are important to define biomass, at least in E. crassipes, 


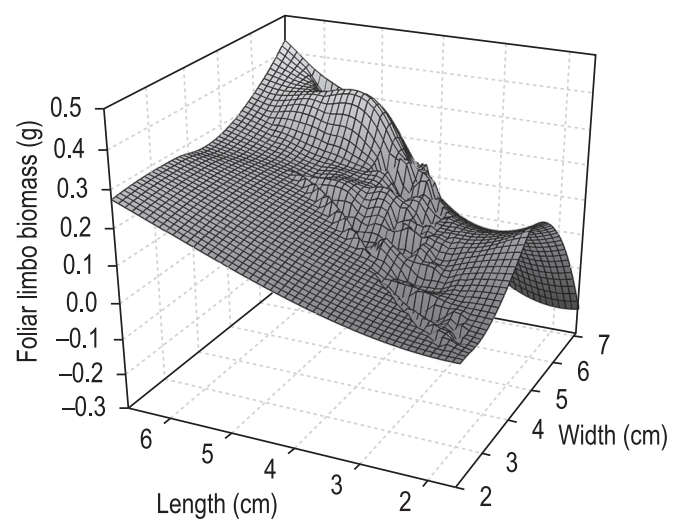

Figure 1. Graphic representation from the width $\mathrm{x}$ length $\mathrm{x}$ biomass for the foliar limbo biomass.

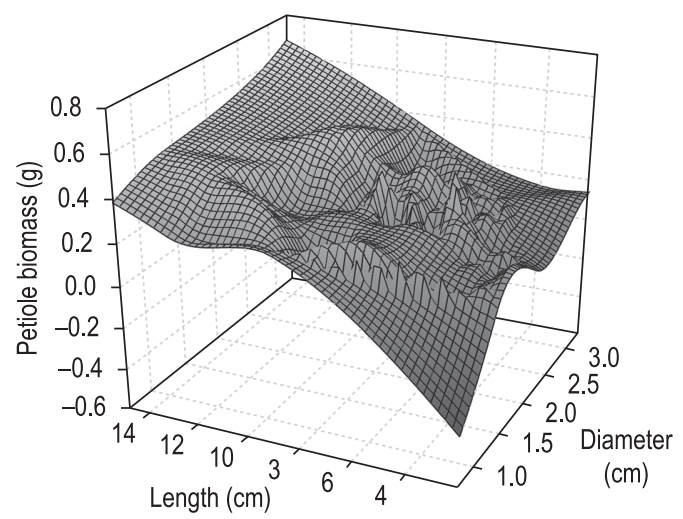

Figure 2. Graphic representation from the diameter $x$ length $\mathrm{x}$ biomass for petiole biomass.

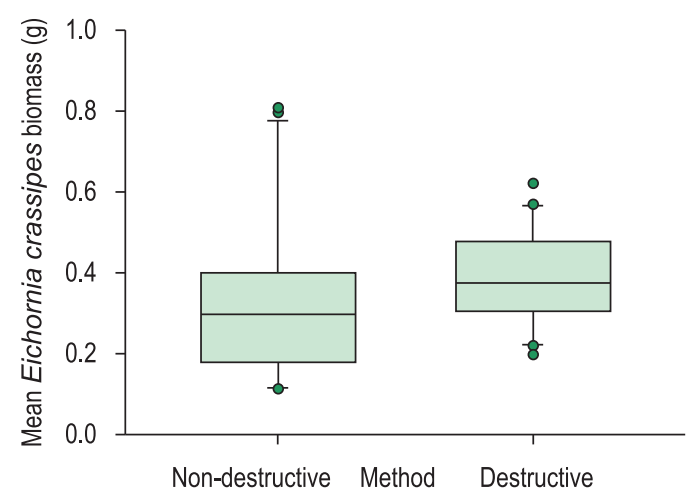

Figure 3. Boxplot of the biomass determination by nondestructive and destructive methods.

considering that the obtained results are not different from those found using the destructive method in samples collected at the same site. In addition, if applied in other studies, such as that of Bownes et al. (2010), the preservation samples as proposed in the present study could allow obtaining complementary results.
Destructive evaluations, which use square sampling, evaluate aquatic macrophyte populations as a whole, and do not allow individual analysis of biomass loss or gain along time. The comparison between the mathematical model presented here to determine biomass and the destructive method shows that the non-destructive method may efficiently estimate $E$. crassipes biomass.

Based on data obtained in this study, we suggest that the Equation 3:

$$
\begin{aligned}
& {[-0.005368-(0.004996 * \mathrm{~W})+} \\
& \left.\left(0.010241 * \mathrm{~L}_{1}\right)+\left(0.07690 * \mathrm{~W} * \mathrm{~L}_{1}\right)\right]
\end{aligned}
$$

Provides an easy and accurate E. crassipes foliar limbo biomass balance estimate, whereas petiole biomass balances may be obtained using that the Equation 4:

$$
\begin{aligned}
& {[-0.011972-(0.019692 * \mathrm{D})+} \\
& \left.\left(0.020722 * \mathrm{~L}_{2}\right)+\left(0.008391 * \mathrm{D} * \mathrm{~L}_{2}\right)\right]
\end{aligned}
$$

These equations present coefficients of determination of 0.90 and 0.79 , respectively. Therefore, Eichornia crassipes biomass can be determined by the sum of limbo and petiole biomass. The use of multiple regression equations using limbo width/length for and petiole width/ diameter is an alternative to destructive methods.

\section{Final Remarks}

The method/model proposed by the present study allows to follow the growth of the same E. crassipes individuals along time time, which may be influenced by environmental factors, as well as by water and nutrient availability. Therefore, the application of the method could not only be used in the biomass analyses of macrophyte communities, but could also contribute to preserve the samples both for research and ecological purposes.

Allometric methods should be further studied, providing, support to new approaches to studies on aquatic macrophyte communities.

\section{Acknowledgements}

The authors thank the Sector of Botany and Paleobotany of Museu de Ciências Naturais of UNIVATES, Limnology Laboratory of Instituto de Biociências of UFRGS. They also thank Professor Adriano Sanches Melo for his meaningful contributions. André Jasper thanks Conselho Nacional de Desenvolvimento Científico e Tecnológico (CNPq) for the fellowship and financial support 


\section{References}

ALVES, LF., MARTINS, FR. and SANTOS, FAM. 2004. Allometry of a neotropical palm, Euterpe edulis Mart. Acta Botanica Brasilica, vol. 18, p. 369-374. http:// dx.doi.org/10.1590/S0102-33062004000200016

BEERAVOLU, CR., COUTERON, P., PÉlisSIER, R. and MUNOZ, F. 2009. Studying ecological communities from a neutral standpoint: A review of models' structure and parameter estimation. Ecological Modelling, vol. 220, p. 2603-2610. http:// dx.doi.org/10.1016/j.ecolmodel.2009.06.041

BOWNES, A., HILL, MP. and BYRNE, MJ. 2010. Evaluating the impact of herbivory by a grasshopper, Cornops aquaticum (Orthoptera: Acrididae), on the competitive performance and biomass accumulation of water hyacinth, Eichhornia crassipes (Pontederiaceae). Biological Control, vol. 53, p. 297303.

CASWELL, H. 1976. Community structure-neutral model analysis. Ecological Monographs, vol. 46, p. 327-354. http://dx.doi.org/10.2307/1942257

Centro de Informações Hidrometeorológicas UNIVATES. 2005. Banco de dados hidrometerológicos da Região do Vale do Taquari - Relatório de Atividades / 2005. Lajeado: Rio Grande do Sul.

CHAVE, J. 2004. Neutral theory and community ecology. Ecolgical Letters, vol. 7, p. 241-253. http:// dx.doi.org/10.1111/j.1461-0248.2003.00566.x

CHAVE, J., ALONSO, D. and ETIENNE, RS. 2006. Comparing models of species abundance. Nature, vol. 441, p. E1-E11. PMid:16672928. http://dx.doi. org/10.1038/nature04826

COSTA, M., 2005. Estimate of net primary productivity of aquatic vegetation of the Amazon floodplain using Radarsat and JERS-1. International Journal of Remote Sense, vol. 26, p. 4527-4536. http://dx.doi. org/10.1080/01431160500213433

DAOUST, RJ. and CHILDERS, DL. 1998. Quantifying aboveground biomass and estimating net aboveground primary production for wetland macrophytes using a nondestructive phenometric technique. Aquatic Botany, vol. 62, p. 115-133. http://dx.doi. org/10.1016/S0304-3770(98)00078-3

DEMARS, BOL. and EDWARDS, AC. 2009. Distribution of aquatic macrophytes in contrasting river systems: A critique of compositional-based assessment of water quality. Science of the Total Environment, vol. 407, p. 975-990. PMid:18977514. http://dx.doi.org/10.1016/j.scitotenv.2008.09.012

DOWNING, JA. and ANDERSON, M. 1985. Estimating the standing biomass of aquatic macrophytes. Canadian Journal of Fishring and Aquatic Science, vol. 2, p. 1860-1869.

DYN, C. 2004. Principles of Mathematical Modelling. $2^{\text {th }}$ ed. Academic Press. 303 p.
ENGLE, DL., MELACK, JM., DOYLE, RD. and FISHER, TR. 2008. High rates of net primary productivity and turnover for floating grasses on the Amazon floodplaIn implications for aquatic respiration and regional $\mathrm{CO}_{2}$ flux. Global Change Biology, vol. 14, p. 1-13.

GAO, L. and LI, B. 2004. The study of a specious invasive plant, water hyacinth (Eichhornia crassipes): achievements and challenges. Acta Phytoecolgica Sinica, vol. 28, p. 735-52.

GOPAL, B. 1987. Water hyacinth - Aquatic Plant Study. Amsterdam: Elsevier. 471 p.

GOURAUd, C., GIROUX, JF., MESLE'ARD, F., DESNOUHES, L. 2008. Non-destructive sampling of Schoenoplectus maritimus in southern France. Wetlands, vol. 28, p. 228-232. http://dx.doi. org/10.1672/07-85.1

GRECO, MKB. and FREITAS, JR. 2002. On two methods to estimate production of Eichhornia crassipes in the eutrophic pampulha reservoir (MG, Brazil). Brazilian Journal of Biology, vol. 62, p. 463-471. http://dx.doi.org/10.1590/S151969842002000300010

HAIRIAH, K., SITOMPULL, SM., NOORDWIJK, Mvan. and PALM, C. 2001. Methods for sampling carbon stocks above and below ground. In NOORDWIJK, Mvan., WILLIAMS, S. and VERBIST, B. (Ed.). Towards integrated natural resource management in forest margins of the humid tropics: local action and global concerns. Bogoi: ICRAF. 49 p. ABS Lecture Note 4.

HENRY-SILVA, GG. and CAMARGO, AFM. 2003. Avaliação sazonal da biomassa da macrófita aquática Eichhornia azurea em um rio de águas brancas da bacia hidrográfica do rio Itanhaém (litoral sul do estado de São Paulo, Brasil). Hoehnea, vol. 30, p. 71-77.

HIGUCHI, N., SANTOS, J., RIBEIRO, RJ., MINETTE, L. and BIOT, Y. 1998. Biomassa da parte aérea da vegetação de floresta tropical úmida de terra-firme da Amazônia Brasileira. Acta Amazonica, vol. 28, p. 153-165.

HOPKINSON, CS., GOSSELINK, JG. and PARRONDO, RT. 1980. Production of coastal Louisiana marsh plants calculated from phenometric techniques. Ecology, vol. 61, p. 1091-1098. http:// dx.doi.org/10.2307/1936828

HUBBELL, SP. 1997. A unified theory of biogeography and relative species abundance and its application to tropical rain forests and coral reefs. Coral Reefs, vol. 16, p. S9-S21. http://dx.doi.org/10.1007/ s003380050237

IRGANG, BE. and GASTAL JUNIOR, CVS. 1996. Macrófitas aquáticas da planície costeira do Rio Grande do Sul. Porto Alegre: UFRGS. 290 p. 
JEPSEN, DB. and WINEMILLER, KO. 2002. Structure of tropical river food webs revealed by stable isotope ratios. Oikos, vol. 96, p. 46-55. http://dx.doi. org/10.1034/j.1600-0706.2002.960105.x

LU, J., WU, J., FU, Z. and ZHU, L. 2007. Water hyacinth in China: a sustainability science-based management framework. Environmental Management, vol. 40, p. 823-830. PMid:17768654. http://dx.doi. org/10.1007/s00267-007-9003-4

LU, J., ZHU, L., HU, G. and WU, J. 2010. Integrating animal manure-based bioenergy production with invasive species control: a case study at Tongren Pig Farm in China. Biomass and Bioenenrgy, vol. 34, p. 821-827. http://dx.doi.org/10.1016/j. biombioe.2010.01.026

MAHUJCHARIYAWONG, J. and IKEDA, S. 2001. Moddelling of environmental phytoremediation in eutrophic river - the case of water hyacinth harvest in Tha-chin River, Thailand. Ecological Models, vol. 142, p. 121-134. http://dx.doi.org/10.1016/S03043800(01)00283-6

MacARTHUR, RH. and WILSON, EO. 1963. An equilibrium theory of insular biogeography. Evolution, vol. 17, p. 373-387. http://dx.doi. org/10.2307/2407089

MARCHI, SR. and PITELLI, RA. 2003. Estimativa foliar de plantas daninhas de ambiente aquático: Eichhornia crassipes. Planta Daninha, vol. 21, p. 109-112.

MIAO, S., SINDØJ, E. and EDELSTEIN, C. 2008. Allometric relationships of field populations of two clonal species with contrasting life histories. Cladium jamaicense and Typha domingensis. Aquatic Botany, vol. 88, p. 1-9. http://dx.doi.org/10.1016/j. aquabot.2007.08.001

MORENO, JA. 1961. Clima do Rio Grande do Sul. Porto Alegre: Secretaria da Agricultura, Divisão de Terras e Colonização. $42 \mathrm{p}$.

MORRIS, JT. and HASKIN, B. 1990. A 5-yr record of aerial primary production and stand characteristics of Spartina alterniflora. Ecology, vol. 71, p. 2209-2217. http://dx.doi.org/10.2307/1938633
PIEDADE, MTF., JUNK, WJ. and LONG, SP. 1991. The productivity of the $\mathrm{C} 4$ grass Echinochloa polystachya on the Amazon floodplain. Ecology, vol. 72, p. $1456-$ 1463. http://dx.doi.org/10.2307/1941118

POTT, VJ. and POTT, A. 2000. Plantas Aquáticas do Pantanal. Brasília: EMBRAPA. 404 p.

SANTOS, AM., AMADO, AM., MINELLO, M. and FARJALHA, VF. 2006. Effects of the sand bar breaching on Typha domingensis (Pers.) in a tropical coastal lagoon. Hydrobiologia, vol. 556, p. 61-68. http://dx.doi.org/10.1007/s10750-005-1084-6

SILVA, TSF., COSTA, MPF. and MELACK, JM. 2010. Assessment of two biomass estimation methods for aquatic vegetation growing on the Amazon Floodplain. Aquatic Botany, vol. 92, p. 161-167. http://dx.doi.org/10.1016/j.aquabot.2009.10.015

SIMPSON, D. and SANDERSON, H. 2002. Eichhornia crassipes, Pontederiaceae. Curtis's Botanical Magazine, vol. 19, no. 1, p. 28-34. http://dx.doi. org/10.1111/1467-8748.00326

SOTI, PG. and VOLIN, JC. 2010. Does water hyacinth (Eichhornia crassipes) compensate for simulated defoliation? Implications for effective biocontrol. Biological Control, vol. 54, p. 35-40. http://dx.doi. org/10.1016/j.biocontrol.2010.01.008

RICKLEFS, RE. 2003. A Economia da Natureza. $5^{\text {th }} \mathrm{ed.}$ Rio de Janeiro: Guanabara Koogan. 503 p.

THOMAZ, SM., BINI, LM. and PAGIORO, TA. 2004. Métodos em limnologia: macrófitas aquáticas. In BICUDO, CEM. and BICUDO, DC. (Org.). Amostragem em Limnologia. São Carlos: RiMa. 371 p.

THURSBY, GB., CHINTALA, MM., STETSON, D., WIGAND, C. and CHAMPLIN, DM. 2002. A rapid, non-destructive method for estimating aboveground biomass of salt marsh grasses. Wetlands, vol. 22, p. 262-630.

WATTERSON, GA. 1974. Models for the logarithmic species abundance distributions. Theoretical Population Biology, vol. 6, p. 217-250. http://dx.doi. org/10.1016/0040-5809(74)90025-2

Received: 11 May 2010 Accepted: 28 February 2011 